\title{
Alien invasive plants in Belgian limestone quarries
}

\author{
Arnaud Monty, Alexis Jorion, Carline Pitz, Charly Géron, Grégory Mahy
}

University of Liège, Gembloux Agro-Bio Tech, Biodiversity and landscape, 2, Passage des Déportés, BE-5030 Gembloux, Belgium.E-mail: arnaud.monty@uliege.be

Received 8 March 2019, accepted 13 June 2019, available online 26 June 2019.

This article is distributed under the terms and conditions of the CC-BY License (http://creativecommons.org/licenses/by/4.0)

Description of the subject. Vegetation of high conservation value can establish in quarries, during or after exploitation. Alien plants could hamper this process and cause additional rehabilitation costs. However, the situation of plant invasion in quarries is largely unknown.

Objectives. We aimed to assess alien plant invasion in active and abandoned quarries, and to identify the most invaded quarry sectors.

Method. We surveyed 6,692 plots in 31 quarries in Belgium and recorded occurrence, density and cover of the 65 listed alien invasive plants in Belgium.

Results. Fourteen species were recorded and 25 quarries contained at least one species. The two most occurring species, Buddleja davidii Franch. and Senecio inaequidens DC., were more widespread in quarries in activity. All sectors of the quarries were affected by alien plant invasion.

Conclusions. Alien plant invasion in limestone quarries is highly variable, but significant. Considering the ecological potential of quarry sites, this issue should be better tackled.

Keywords. Buddleja davidii, Senecio inaequidens, invasive species, mining, plant cover.

\section{Plantes exotiques envahissantes dans les carrières calcaires de Belgique}

Description du sujet. Une végétation de haute valeur conservatoire peut s'établir dans les carrières, pendant ou après l'exploitation. Les plantes exotiques peuvent empêcher ce processus et représenter des couts supplémentaires lors de la réhabilitation. La situation concernant les invasions végétales en carrières est largement méconnue.

Objectifs. L'objectif était de quantifier les invasions végétales en carrières calcaires (en activité ou non) et d'identifier les secteurs des carrières les plus envahis.

Méthode. Nous avons échantillonné 6692 placettes dans 31 carrières en Belgique et noté l'occurrence, la densité et le recouvrement des 65 espèces exotiques envahissantes listées au niveau belge.

Résultats. Quatorze espèces ont été observées et 25 carrières contenaient au moins une espèce. Les deux espèces les plus fréquentes, Buddleja davidii Franch. et Senecio inaequidens DC., étaient plus répandues dans les carrières en activité. Tous les secteurs étaient concernés par les invasions.

Conclusions. La problématique des plantes exotiques envahissantes dans les carrières calcaires est très variable, mais significative. Vu le potentiel écologique de ces sites, celle-ci devrait être mieux prise en compte.

Mots-clés. Buddleja davidii, Senecio inaequidens, espèce envahissante, industrie minière, recouvrement végétal.

\section{INTRODUCTION}

Herbaceous plant assemblages of high conservation value, e.g. calcareous grasslands, can spontaneously develop or be implemented in limestone quarries (Prach et al., 2013; Pitz et al., 2018). However, invasion by exotic plants may represent a challenge to biodiversity conservation and ecological restoration in quarries (Hobbs \& Huenneke, 1992; Pitz et al., 2019), since it can hamper the installation of native plants or alter ecosystem functioning (Vilà et al., 2011). It can also increase rehabilitation costs and alter the corporate image of mining companies through negative publicity on nature conservation issues.

Human activity and disturbances have long been recognized as drivers of plant invasions (e.g. Alston \& Richardson, 2006; Monty et al., 2013). Current operational quarries are generally larger; host more diverse machinery and more abundant transporter traffic than ancient (abandoned) quarries. As such, they 
might be more easily invaded, notably by colonizers, i.e. early successional species (Rejmanek, 1989).

Limestone quarries exhibit a variety of habitat types, notably due to the exploitation that requires the delimitation of sectors. The topsoil is removed and piled on embankments that can serve as physical barriers reducing noise and dust pollution. The rock is blasted in the extraction pit and transported to the factory where it is processed and stocked. The rest of the excavated material is disposed on site in the form of spoil heaps. Several water bodies are also present. In some cases, parts of the quarry have been rehabilitated into forest or agricultural areas. As not all sectors have the same ecological conditions, they do not have the same ecological potential.

If previous studies have reported the occurrence of particular invasive plants in limestone quarries (e.g. Prach et al., 2013; Gilardelli et al., 2015), no studies to date have evaluated the general situation of plant invasion. The present study aims at:

- quantifying the occurrence, density and cover of alien invasive plants;

- comparing the situation of alien plant invasion between active and abandoned quarries;

- identifying the most invaded quarry sectors.

\section{MATERIALS AND METHODS}

\subsection{Field survey}

The study was performed in 31 limestone quarries in Southern Belgium (Figure 1a), with a minimum area of 5 ha. All sites were limestone quarries, i.e. sites where calcareous rocks (limestone sensu stricto, dolostone, tuffeau stone or chalk) or limestone gravel were being extracted or have been extracted in the past. Fifteen quarries were still operational, whereas the 16 others were abandoned for at least five years. The quarries and sectors within quarries were digitalized using ArcMap 10.3 (ESRIC). The sectors were delimited as: facilities (buildings, roads and parking lots); extraction pit; spoil heaps; embankments; stocks; agricultural lands; forests; and water bodies. The latter was not surveyed for security reasons.

The surveyed species were the 65 plant species of the official list of alien invasive species in Belgium (Branquart, 2016). Plots of $2 \mathrm{~m} \times 10 \mathrm{~m}$ were surveyed across sites using a random walk (Figure 1b): after the first plot had been randomly located and surveyed, the operator walked $10 \mathrm{~m}$ in a random direction then located another plot to survey, and so on, until the operator had surveyed $1 \%$ of the site area. In the six largest sites (more than 80 ha) however, the number of plots was limited to 800 . Each plot was assigned to a sector. If a plot covered two different sectors, it was
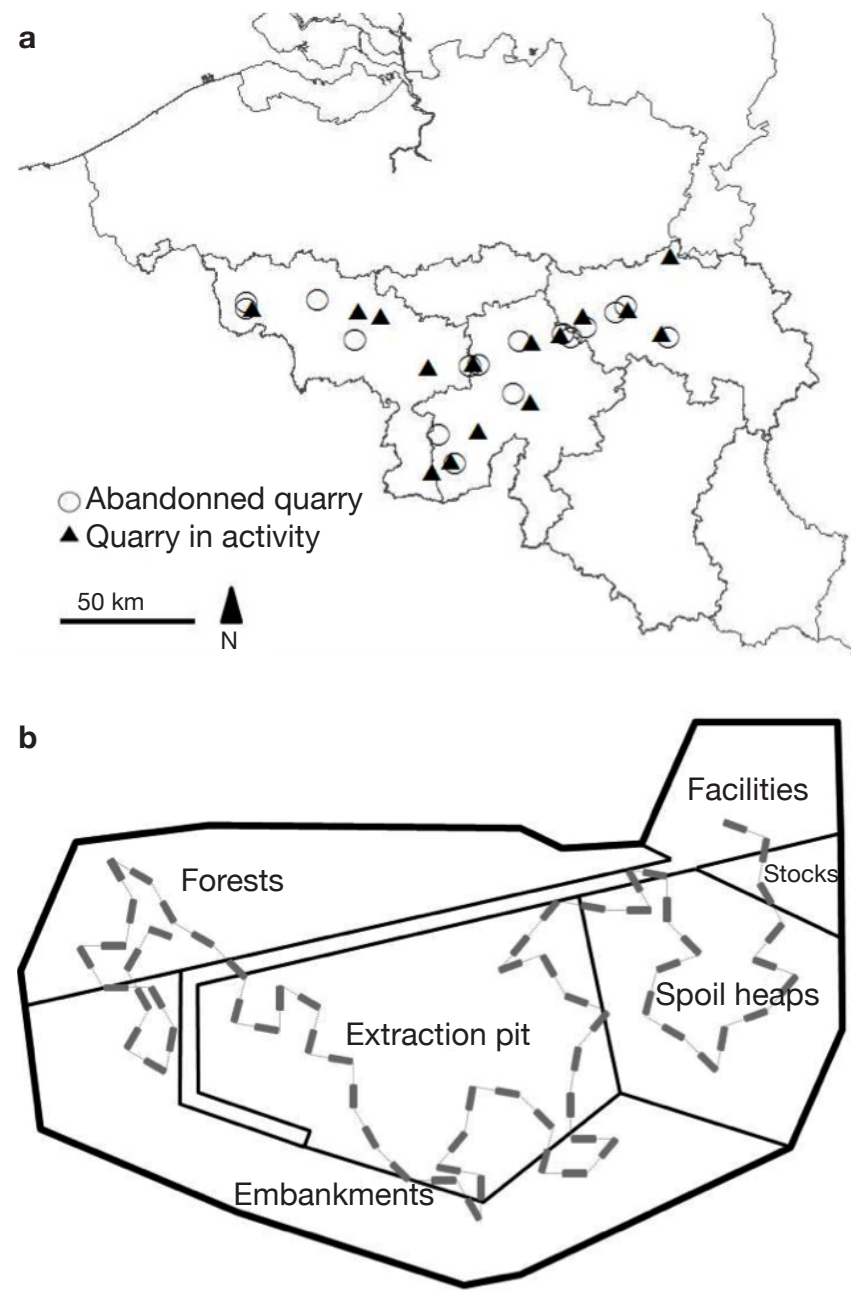

Figure 1.a. Map of the 31 sampled quarry sites in Southern Belgium. b. Schematic representation of the sampling design. Sectors of the quarry are delineated in black. The grey rectangles represent the plots and the dashed grey line represents the random walk $-\boldsymbol{a}$. Carte des 31 sites carriers échantillonnés en Wallonie. $\boldsymbol{b}$. Représentation schématique de l'échantillonnage. Les secteurs de la carrière sont délimités en noir. Les rectangles gris représentent les parcelles et la ligne pointillée grise les reliant représente la marche aléatoire.

assigned to the sector containing the largest proportion of the plot. A total of 6,692 plots (4,619 in active and 2,073 in abandoned quarries) were surveyed.

For each plot, the presence, the number of individuals and the cover of all alien invasive plant species were recorded. For clonal species, ramets were considered as individuals. The cover was estimated according to the modified Braun-Blanquet scale (Barkman et al., 1964).

\subsection{Data analyses}

The species occurrence (\%) was calculated as the proportion of quarries where the species was present. 
The density of each species was calculated as the number of individuals per unit area and expressed in individuals $\cdot \mathrm{ha}^{-1}$. A Kruskal-Wallis test with the quarry activity as fixed factor (active $v s$ abandoned) was performed using the number of occurring species in each site. A Kruskal-Wallis test with the quarry activity as fixed factor, using the average density and average cover at the site level, was performed for each species and for all species together. The average cover of each species was calculated based on the median value of each Braun-Blanquet class. The proportion of invaded plots was calculated for each sector $i$ present in each quarry $j$ as $P_{i j}=N_{i j} / T_{i j}$, where $N$ is the number of plots where at least one invasive species was found and $T$ the total number of plots. For active and abandoned quarries separately, a Kruskal-Wallis test was performed on the proportion of invaded plots with the sector as fixed factor.

\section{RESULTS}

In total, 14 alien invasive plant species were recorded. Their occurrence, average density and average cover in active and abandoned quarries are synthesized in table 1. Alien invasive species were recorded in 25 out of the 31 quarries. The three most occurring species were Buddleja davidii Franch. (19 quarries, $61 \%$ ), Senecio inaequidens DC. (17 quarries, 55\%) and Robinia pseudoacacia L. (14 quarries, 45\%). The number of species ranged from 0 to 8 in active quarries and from 0 to 6 in abandoned ones, with medians of respectively 3 and 1 species. The Kruskal-Wallis test showed a difference close to significance in the number of occurring species according to quarry activity $(\mathrm{H}=$ $3.39 ; \mathrm{DF}=1 ; p=0.066)$. The density and cover of all species considered together did not significantly differ between active and abandoned quarries (respectively $\mathrm{H}=2.84 ; \mathrm{DF}=1 ; p=0.092$ and $\mathrm{H}=1.19 ; \mathrm{DF}=1 ; p=$ $0.275)$.

It is worth noting that three species of woody alien invasive plants (Rosa rugosa Thunb.; Prunus serotina Ehrh.; and Quercus rubra L.) were only recorded in active quarries, whereas four other species (Fallopia sachalinensis [F.Schmidt] Ronse Decr.; Ailanthus altissima [Mill.] Swingle; Rhus typhina L. and Mahonia aquifolium [Pursh] Nutt.) were only found in abandoned quarries.

When considering each species separately, significant effects of the quarry activity were found for B. davidii density $(\mathrm{H}=5.48 ; \mathrm{DF}=1 ; p=0.019)$ and for $S$. inaequidens density $(\mathrm{H}=7.38 ; \mathrm{DF}=1 ; p=0.007)$ and cover $(\mathrm{H}=6.94 ; \mathrm{DF}=1 ; p=0.008)$. These two species were more widespread in active quarries.

The proportion of invaded plots significantly varied among sectors in active quarries $(\mathrm{H}=11.26 ; \mathrm{DF}=4$; $p=0.024$ ), being highest for spoil heaps (Figure 2). In abandoned quarries, no significant difference was found $(\mathrm{H}=7.23 ; \mathrm{DF}=6 ; p=0.300)$. It has to be noted that not all sectors were present or sampled in all quarries.

\section{DISCUSSION}

Our results indicate a significant level of alien plant invasion in limestone quarries, but with a high heterogeneity. Two highly occurring and widespread species, $B$. davidii and $S$. inaequidens, are pioneer wind-dispersed species typical of dry and open habitats (Hill et al., 2002; Monty et al., 2008). In active quarries these two species are most abundant and the number of occurring species is slightly higher. This can hamper future ecological restoration in those sites. However the overall density and cover of alien invasive plants did not significantly differ based on quarry activity. This indicates that disturbances are not the sole driver of plant invasion and highlights the continuation of the invasion process after the cease of the quarrying

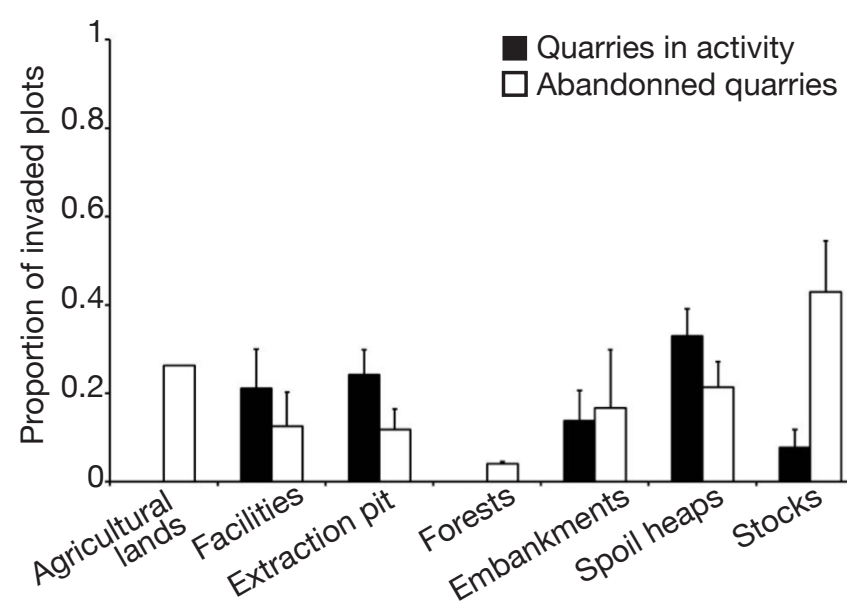

Figure 2. Average proportion of invaded plots ( \pm standard errors) in the different sectors of quarries, for quarries in activity and abandoned quarries. The proportion is calculated for each quarry as the ratio between the number of plots of the considered sector where at least one invasive plant was recorded and the total number of plots of the considered sector. The sectors "agricultural lands" and "forests" were not sampled in quarries in activity - Proportion moyenne de parcelles envahies ( \pm erreur standard) dans les différents secteurs des carrières, pour les carrières en activité et abandonnées. La proportion est calculée, pour chaque carrière, comme le ratio entre le nombre de parcelles $d u$ secteur considéré où au moins une espèce exotique envahissante fut observée et le nombre total de parcelles $d u$ secteur considéré. Les secteurs "agricultural lands" (terres agricoles) et "forests" (forêts) ne furent pas échantillonnés dans les carrières en activité. 


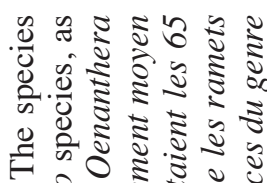
म 80.0 .

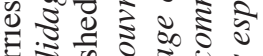

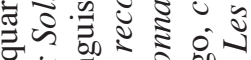
च.

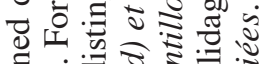

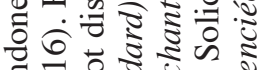

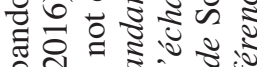
สิ

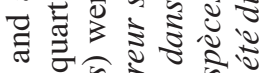

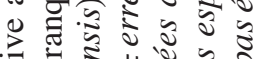

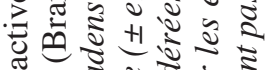
. 券 जै बं के 0.

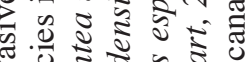

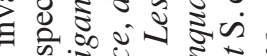

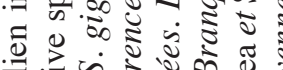
光

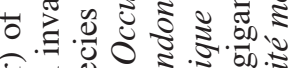

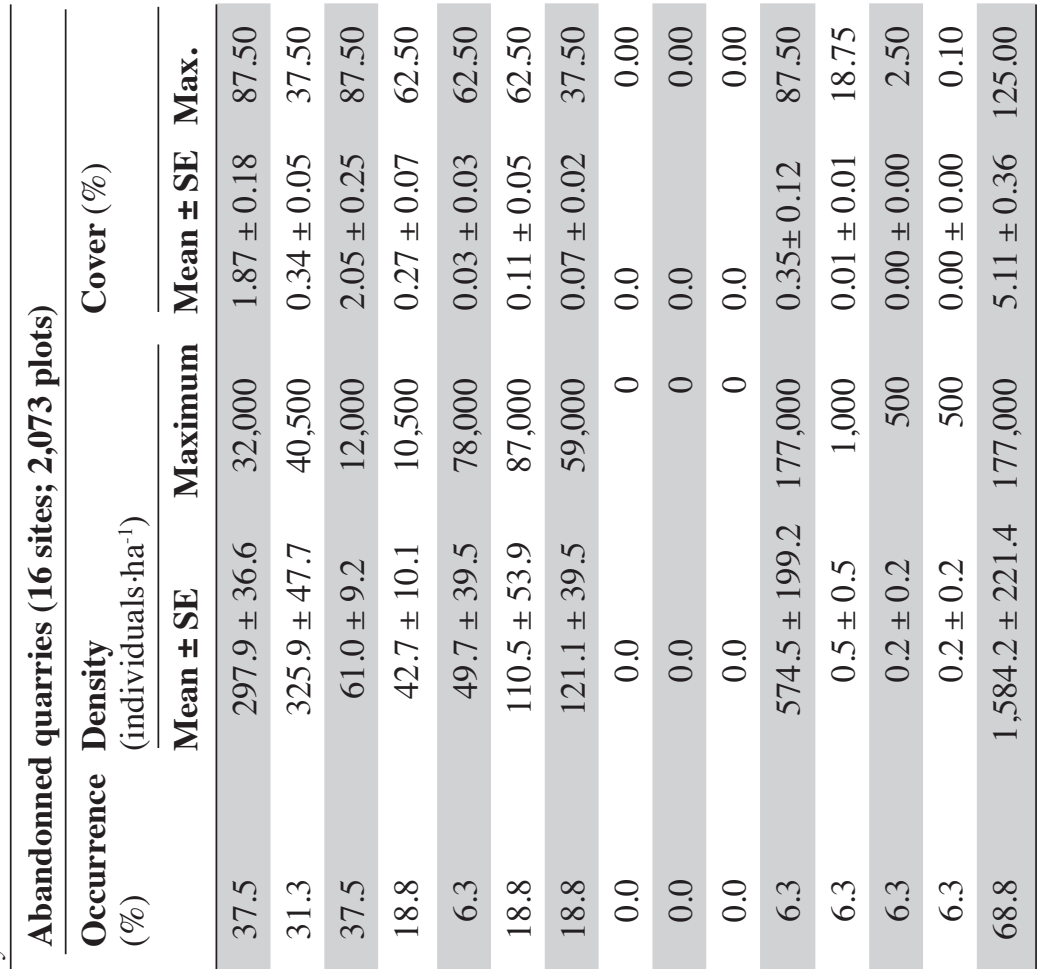

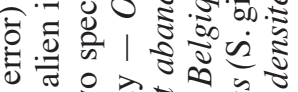
बส

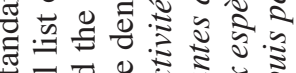
政雪

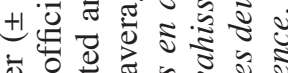
ว

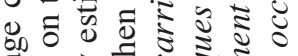
记

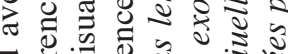

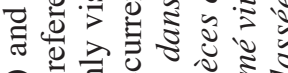
สิ ปั

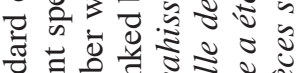

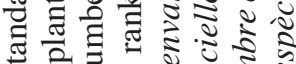

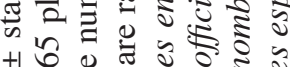

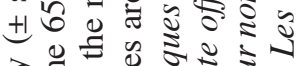

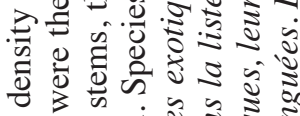
क्ष

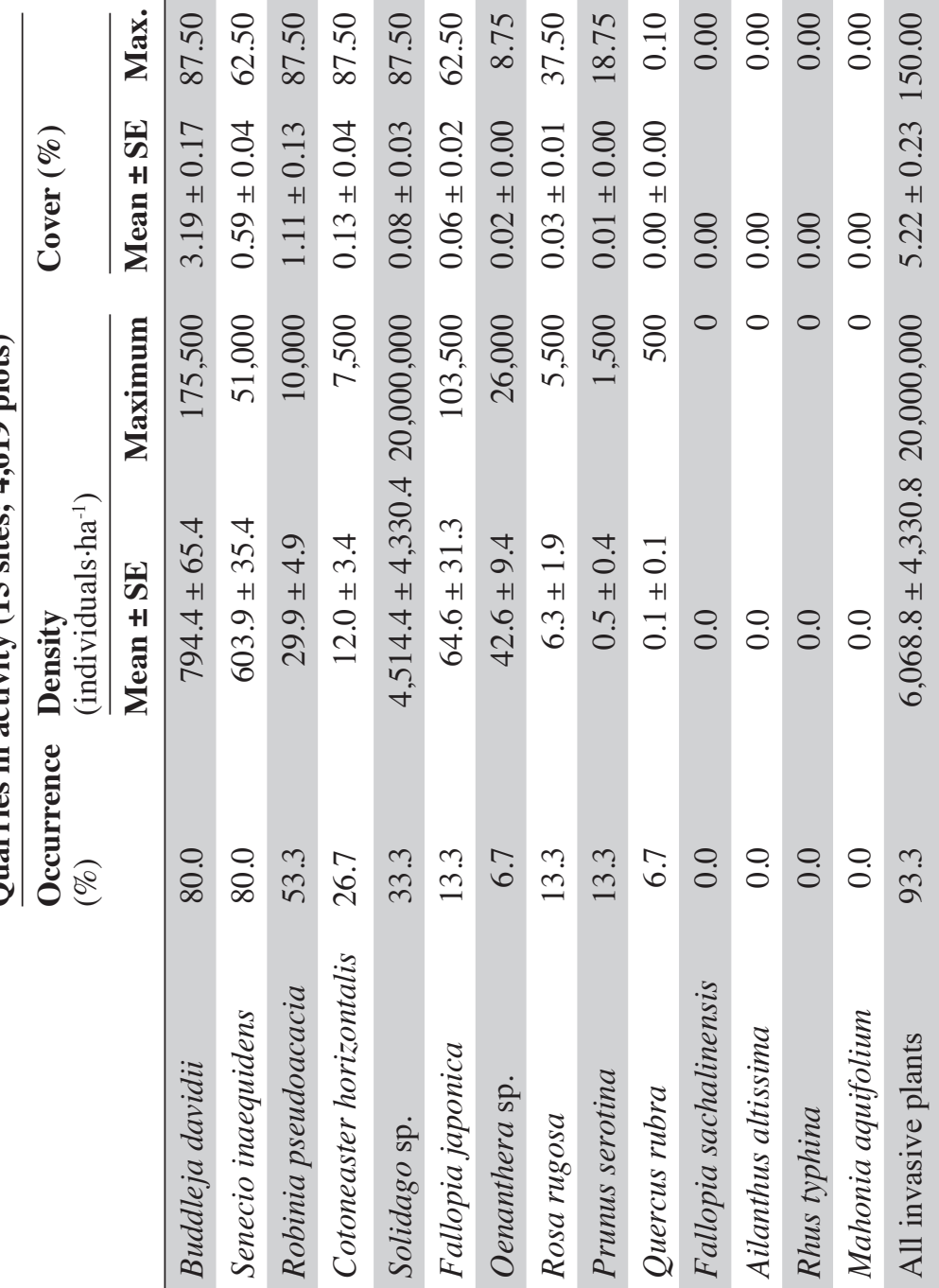

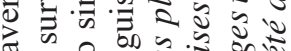

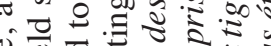
\& ప J) ల.].

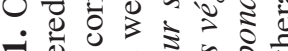

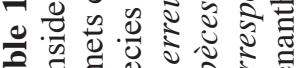

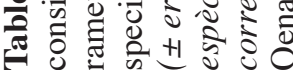

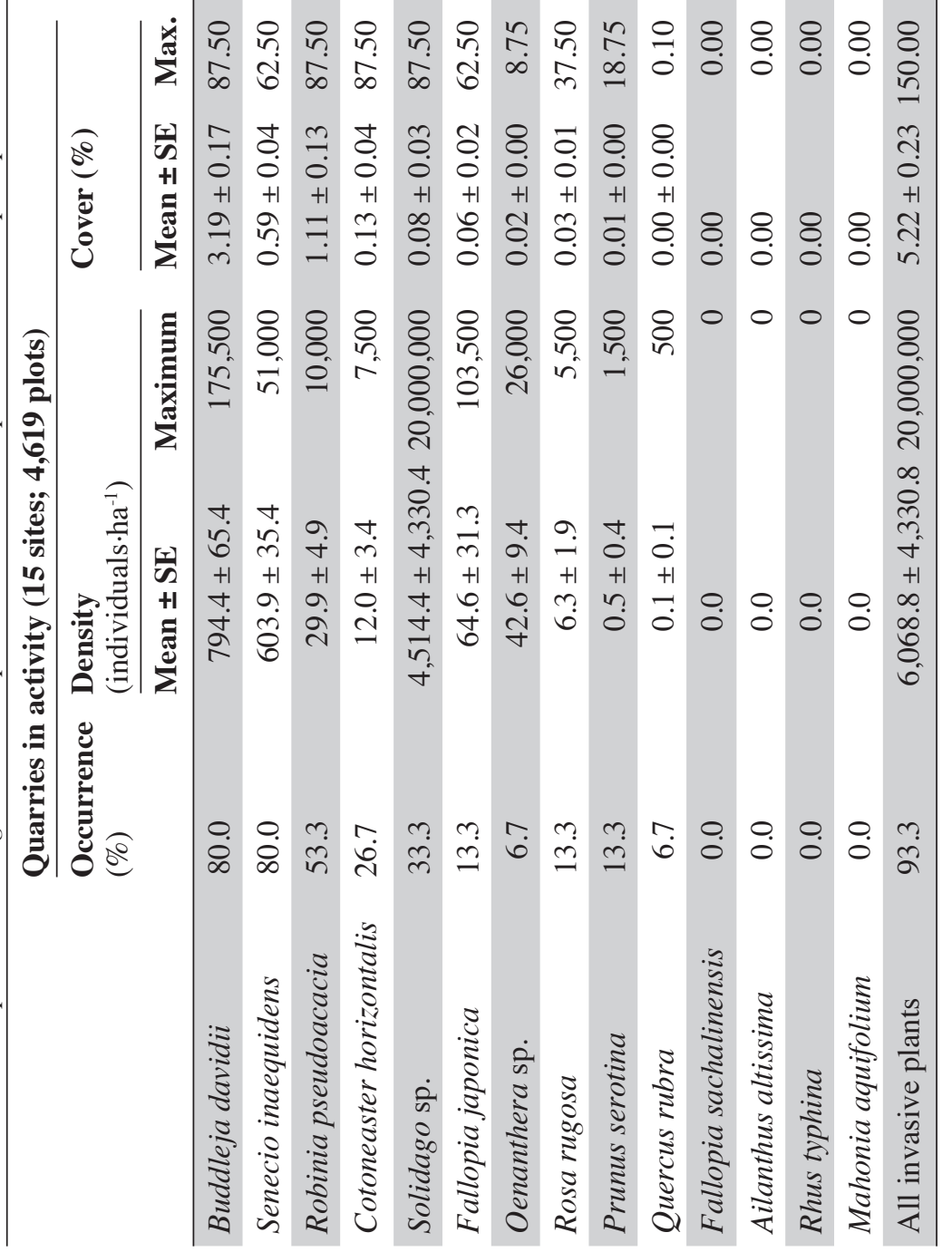


activity. Our survey notably revealed the importance of intentionally planted trees and shrubs, such as $R$. pseudoacacia, Cotoneaster horizontalis Decne., $R$. rugosa and P. serotina. Considering the ecological potential of quarry sites, managing plant invasions appears to be a necessity. It is important, from a cost/ benefit point of view, to address the problem early in the invasion process. Preventing the introduction of the species recorded in this study in non-invaded quarries is a key aspect in the management of the problem. In parallel, running regular vegetation surveys should make early detection and eradication of emergent species feasible at minimal costs.

\section{CONCLUSIONS}

Our survey revealed the importance of alien invasive plants in quarries and emphasizes the need for managing the issue. Woody species have often been intentionally planted for rehabilitation, in abandoned sites but also in active quarries. This should be highly discouraged.

\section{Bibliography}

Alston K.P. \& Richardson D.M., 2006. The roles of habitat features, disturbance, and distance from putative source populations in structuring alien plant invasions at the urban/wildland interface on the Cape Peninsula, South Africa. Biol. Conserv., 132, 183-198.

Barkman J.J., Doing H. \& Segal S., 1964. Kritische Bemerkungen und Vorschläge zur Quantitativen Vegetationsanalyse. Acta Bot. Neerl., 13(3), 394-419.

Branquart É., 2016. Alert, black and watch lists of invasive species in Belgium. Harmonia version 1.2, Belgian Forum on Invasive species, http://ias.biodiversity.be, (01/04/2016).
Gilardelli F. et al., 2015. Ecological filtering and plant traits variation across quarry geomorphological surfaces: implication for restoration. Environ. Manage., 55, 11471159.

Hill M.O., Roy D.B. \& Thompson K., 2002. Hemeroby, urbanity and ruderality: bioindicators of disturbance and human impact. J. Appl. Ecol., 39, 708-720.

Hobbs R.J. \& Huenneke L.F., 1992. Disturbance, diversity and invasion: implications for conservation. Conserv. Biol., 6, 324-337.

Monty A. et al., 2008. Seed rain pattern of the invasive weed Senecio inaequidens (Asteraceae). Belg. J. Bot., 141, 51-63.

Monty A., Brown C.S. \& Johnston D.B., 2013. Fire promotes downy brome (Bromus tectorum L.) seed dispersal. Biol. Inv., 15, 1113-1123.

Pitz C., Piqueray J., Monty A. \& Mahy G., 2018. Naturally recruited herbaceous vegetation in abandoned Belgian limestone quarries: towards Natura 2000 habitats analogues? Folia Geobot., 53, 147-158.

Pitz C. et al., 2019. Comparison of mining spoils to determine the best substrate for rehabilitating limestone quarries by favoring native grassland species over invasive plants. Ecol.Eng., 127, 510-518.

Prach K. et al., 2013. Spontaneous vegetation succession at different central European mining sites: a comparison across seres. Environ. Sci. Pollut. Res., 20, 7680-7685.

Rejmanèk M., 1989. Invasibility of plant communities. In: Drake J.A. et al., eds. Biological invasions: a global perspective. Chichester, UK: John Wiley \& Sons, 369388.

Vilà M. et al., 2011. Ecological impacts of invasive alien plants: a meta-analysis of their effects on species, communities and ecosystems. Ecol. Lett., 14(7), 702708.

(13 ref.) 